\title{
IMMUNITY AND CANCER: ROLE OF TUMOR-INFILTRATING LYMPHOCYTES IN TRIPLE-NEGATIVE BREAST CANCER
}

\author{
ANA TEČIĆ VUGER ${ }^{1}$, ROBERT ŠEPAROVIĆ ${ }^{1,4}$, LJUBICA VAZDAR ${ }^{1}$, MIRJANA PAVLOVIĆ ${ }^{1}$ \\ PETRA LINARIC ${ }^{1}$, SANDA ŠITIĆ ${ }^{2}$, MARTINA ŠEPETAVC ${ }^{3}$ and DAMIR VRBANEC ${ }^{4}$ \\ ${ }^{1}$ Division of Medical Oncology, University Hospital for Tumors, \\ Sestre milosrdnice University Hospital Center; \\ ${ }^{2}$ Department of Oncological Pathology and Clinical Cytology, University Hospital for Tumors, \\ Sestre milosrdnice University Hospital Center; \\ ${ }^{3 \prime}$ Farmacia' Community Pharmacies Chain, Zagreb, Croatia; \\ ${ }^{4}$ Medical School, University of Juraj Dobrila, Pula, Croatia
}

\begin{abstract}
Summary
Tumor stimulates specific innate and acquired immune mechanisms. Main carriers of body's immune response to tumor are T lymphocytes and main mechanism is killing of tumor cells by cytotoxic T lymphocytes CD8 +. In some cases, immune system can also have a protumor role, which is a paradox, given that it is known that the inflammatory state promotes tumor growth. One of the major characteristics of tumors is the evading of immune response, in particular by mechanisms of inhibition of active antitumor immune response via two major physiological inhibitory signals, CTLA-4 and PD1 / PDL1. Blockade of these checkpoints, that are T cell inhibitory mechanisms, has recently yielded best results in an immunotherapy approach to cancer treatment. Immune infiltrate in the tumor, as evidence of existence of an active intrinsic response of the organism, is heterogeneous, and composition often differs between different tumors and tumor cells, and mainly divides into two main cell lines: lymphoid and myeloid. On type of cell lines in the immune infiltrate and their activation and orientation depends the clinical response in different tumors. It is well known that immune infiltrate, especially tumorinfiltrating lymphocytes (TILs), can be predictive of response to therapy and have a prognostic role. In some solid tumors they are a good sign, while in some they signal worse prognosis. Numerous studies have evaluated role of lymphocytic infiltrate in breast cancer (BC) and, based on this knowledge, first consensus on standardization of TILs evaluation in solid tumors has been established on the BC model. Prognostic role of TILs in triple-negative breast cancer has received the most attention.
\end{abstract}

KEYWORDS: antitumor immune response, tumor-infiltrating lymphocytes, immunotherapy, triple-negative breast cancer

\section{IMMUNITY AND CANCER}

\section{Tumor antigens}

Despite being produced by the cells of the host organism, the tumor cells for the immune

Corresponding Author: Ana Tečić Vuger, Division of Medical Oncology, University Hospital for Tumors, Sestre milosrdnice University Hospital Center, Ilica 197, 10000 Zagreb. E-mail: ana.tecic@yahoo.com system represent a foreign body and the immune system responds to them. Tumor immunogenicity, ie the ability to elicit an immune response of the organism, is generated by tumor antigens (1). There are several categories of tumor antigens. Most of these are protein neo-antigens resulting from sporadically mutated genes, (so-called passenger mutations), and less often due to mutations in oncogenes or tumor suppressor genes involved 
in oncogenesis (so-called driver mutations). Another type are oncoviral antigens, that is, products of oncogenic viruses, which can elicit a specific $T$ cell response. The third category includes overexpressed cellular proteins. These are the products of genes that are silenced in normal cells and released in tumor cells or proteins present in normal cells but overproduced in the tumor. These are, for example, cancer - testis antigens (CTA), such as MAGE, an oncogenic variant of the epidermal growth factor HER2 / Neu, and differentiation antigens such as CD on lymphoma and leukemia cells. Tumor antigens also include various alterated glycolipids and glycoproteins, as well as oncofetal antigens alpha feto protein (AFP) and carcinoembryonic antigen (CEA) $(1,2)$.

\section{Immune response}

The physiological role of the immune system is immunosurveillance $(1,3)$, the recognition and destruction of clones of transformed cells before they grow into a tumor and the killing of tumors. Evidence that this surveillance system is needed is also the fact that an increased incidence of a number of tumors appears in an immunocompromised organism, but also that is imperfect - the fact that also in an immunocompetent organism some tumors escape immune control and develop. Tumor stimulates specific innate and acquired immune response mechanisms. The main carriers of the body's immune response $(1,4)$ to tumor are T lymphocytes and the main mechanism is the killing of tumor cells by cytotoxic T lymphocytes CD8 + (CTL). CTLs conduct immune surveillance by recognizing and killing potentially malignant cells expressing peptides of tumor antigen origin, presented in interaction with major histocompatibility class I (MHC I) molecules. Thus, in order for CD8 + CTL to function, the presentation of tumor antigens by antigen presenting cells (APC), usually dendritic cells, is required in MHC I. Also, APC express costimulatory molecules, and those and simultaneously activated helper $\mathrm{T}$ lymphocytes send major signals for differentiation of naive CD8 + T lymphocytes into competent CTLs. CD4 + helper T lymphocytes contribute to the antitumor immune response in many ways: Th1 cells enhance the CD8 $+\mathrm{T}$ cell response and activate macrophages by secreting TNF and IFN $\gamma$, which enhances MHC I. In addition to T cells, the host organism often produces antibodies against tumor antigens, but the significance of them is not completely clear. Natural killer (NK) cells are capable of killing different types of tumor cells. Tumor cells become susceptible to NK cell killing when MHC I expression is reduced or the expression of ligands that bind to activating NK cell receptors is increased, and cytokines such as IL-2 and IL-15 stimulate NK cells. Depending on the state of activity, macrophages can inhibit or promote tumor growth. Classic M1 activated macrophages kill various types of tumor cells. They are activated by the described IFN $\gamma$ production process by Th1 helper CD4 + lymphocytes, and it is not clear how they are activated by tumors $(1,4,5)$.

\section{Protumor role of immunity}

In some cases, the immune system may also have a protumor role. It has long been known that chronic inflammation is a risk factor for the development of many tumors $(1,6)$ although the exact mechanism of this cascade is unknown. Among immune cells, cells of innate immunity are considered the key culprits for protumor effects. Tumorassociated macrophages (TAM) of the alternatively activated M2 phenotype, as well as some other cells, are the source of vascular endothelial growth factor (VEGF), which promotes angiogenesis as well as extracellular space-modifying enzymes, thereby supporting tumor growth and spread. By accumulating free radicals, cells of innate immunity contribute to DNA damage and mutations, which lead to malignant alteration, and by secreting soluble factors such as NFkB support the progression and survival of tumor cells. Alternatively activated M2 macrophages and myeloid-derived immunosuppressive cells, MDSC, indirectly support tumor growth by suppressing effective antitumor immunity. In response to the tumor, dendritic cells can condition the differentiation of CD4 + into anti-inflammatory Th2 cells and T regulatory cells, which suppress the tumor-killing immune response and support the development of M2 and other protumor cell lines. The described protumor effects of the anti-inflammatory mechanisms of the immune system are somewhat paradoxical, since it is known, as described above, that the inflammatory state promotes tumor growth, and therefore finding a balance between the described mechanisms is a challenge for potential therapeutic interventions $(1,6)$. 


\section{Immunoediting and tumor escape}

One of the major characteristics of tumors is evading the immune response. This suggests that the immune control of the host organism over the tumor is only one of the possible variants, that is, the phase in the interaction with the tumor, and that the interaction of the tumor and the host is best described through the process of immunoediting. Immunoediting (7) involves the interaction of a tumor and host organism, which takes place in three stages. The first phase is the elimination phase, a stage where the mechanisms of immune control are adequately functional and eliminate potentially malignant altering cells and tumors. In the equilibrium phase, the coexistence of the host and the tumor is achieved, that is, the host immune system does not eradicate the tumor cells although they do not progress but are dormant. The third phase is the tumor escape phase from immune surveillance. The mechanisms of avoidance of immune surveillance by tumors are generally categorized as either active inhibition of the antitumor immune response or loss of antigens that stimulate these immune responses (1). Inhibition of an active antitumor immune response is accomplished in several ways: by the interaction of inhibitory molecules on the $\mathrm{T}$ cell surface and APC, which otherwise have the function of preventing autoimmune reactions, with ligands, or cofactor molecules on the tumor surface, then suppressing the antitumor response by secreted molecules, such as TGF $\beta$, by producing regulatory $\mathrm{T}$ cells that are actually immunosuppressive in nature and by accumulating the described immature MDSC, a heterogeneous group of cells, such as dendritic, monocytes, and neutrophils that suppress innate immunity and T-cell-mediated antitumor immune mechanisms, either by secretion of immunosuppressive cytokines or by stimulating the accumulation of regulatory $\mathrm{T}$ cells. The best known inhibitory signaling pathways of $\mathrm{T}$ cells and APC, which naturally serve mainly to avoid and control autoimmune responses, and in the case of tumor escape are the most commonly abused pathways to immune surveillance are the signaling pathways via CTLA - 4 and PD - $1(1,7,8)$. Beside of the described mechanisms of inhibition of the active antitumor immune response, the avoidance of immune control of the tumor also allows the loss of expression of tumor antigens, ie the decrease in immunogenicity, which is usually accompanied by the decreased activity of antigen presenting molecules (1).

\section{Immunotherapy approaches}

Immunotherapy is defined as any attempt to use any component of the immune system to enhance an intrinsic host response to a tumor (9). There are two main principles in the immunotherapy approach: both innate and acquired immunity are involved in the fight against tumors, by mechanisms similar to those used to fight external pathogens, and tumor oncogenesis and progression occur through the selection and outgrowth of tumor cells with reduced immunogenicity, and with the creation of an immunosuppressive microenvironment (10). Therefore, therapeutic strategies have focused on stimulating both immune mechanisms, to induce tumor cell death. These strategies include therapy with various cytokines, growth factors, and immunomodulatory agents, impact on the tumor microenvironment, passive immunotherapy with monoclonal antibodies, vaccination with tumor antigens, adoptive cell therapy with antitumor T cells, and blockade of checkpoints ( $\mathrm{T}$ cell inhibitory pathways). Blockade of checkpoints, or $\mathrm{T}$ cell inhibitory mechanisms, has recently yielded the best results in an immunotherapy approach to cancer treatment and gave some hope that acting on the immune system in the fight against tumors would surely bring about solutions that could not have been hoped for in the era of classic nonselective cytotoxic therapy. Checkpoint inhibitors have been developed and proven in preclinical and more recently phase I, II, and III clinical trials and approved in the treatment of numerous solid tumors and hemoblastoses (11). They act on the principle of inhibiting inhibition, mainly in two ways: by interfering with the inhibitory CTLA-4 pathway and interfering with the PD-1 / PDL-1 inhibitory pathway. By binding to a $\mathrm{T}$ cell receptor in one case, a costimulatory molecule in the second case, or a ligand on a tumor cell in the third case, inhibitors, which are monoclonal antibodies in structure, harbor inhibitory molecules and thus release $\mathrm{T}$ cell mechanisms of previous inhibition and allow active antitumor response, which was missing (10). Pembrolizum$\mathrm{ab}(12)$ and atezolizumab (13) have shown the best results in the treatment of breast cancer to date, 
and their efficacy is most significant in the treatment of TNBC.

\section{TUMOR - INFILTRATING LYMPHOCYTES}

\section{The origin, composition and role of immune infiltrate in tumor}

Tumor is a complex system, composed of two main components: tumor cells and stromal compartment. The stromal compartment is composed of normal host cells and tissue, such as fibroblasts and vasculature cells, nerves, and extracellular matrix molecules, which support the biochemical and structural environment that ensures tumor survival (10). Immune cells, or immune infiltrate, are one of the major host cell lines in this stromal compartment. The immune infiltrate in a tumor is heterogeneous, and the composition often varies among different tumors and tumor sites (14). It is mainly divided into two main cell lineages: lymphoid and myeloid. Research evidence to date indicates that myeloid leukocyte cells, such as TAM, dendritic cells (DC) and MDSC, are primarily responsible, through the factors they produce, for the creation of microenvironment in the direction of an immunostimulatory antitumor or tumorsupporting, and antitumor $\mathrm{T}$ cells, by migration into such environments can consequently be activated or suppressed. Conversely, $\mathrm{T}$ cells themselves regulate macrophage recruitment in the direction of functional M1 or protumor M2, indicating the importance of intercellular interaction (1). Likewise, the type of cell lines in the immune infiltrate determine the clinical response in different tumors (10). Acquired immunity mediated by $\mathrm{T}$ and B lymphocytes is known to play a key role in effective antitumor response, and infiltration by cytotoxic CD8 + cells has been shown to be associated with better response to therapy and survival (15). The presence of CD4 + regulatory lymphocytes can be prognostically both good and bad (10), and of the other cellular subpopulations, IFN $\gamma$-secreting Th1 cells have been shown to be associated with a good prognosis (16) and Th2 with a decrease in antitumor response (17). The presence of Th17 cells, the producer of the proinflammatory cytokines IL - 17, has variable effects depending on the cytokine environment in which they are located, which may also depend on the type of tumor and the organ site $(1,10)$. The pre- cise role of B lymphocytic infiltrate is still not completely clear. In conclusion, the presence of CD8 +, Th1, NK, M1, and DC1 is associated with a good antitumor response, and the presence of Th2, M2, DC2, MDSC, and FOXP3 + regulatory T lymphocytes, which secrete IL - 10 and TGF $\beta$, has immunosuppressive effects $(1,10)$ CTLA-4, PD1 and PDL1 are expressed on immune infiltrate cells, especially cytotoxic CD8 + lymphocytes, as well as on tumor cells, which, as previously described, are of particular importance today as targets for immunotherapy (18).

\section{Tumor - infiltrating lymphocytes in solid tumors}

As mentioned above, the composition of the immune infiltrate may vary, depending on the tumor and the organ site. Also, depending on the composition of the immune infiltrate in individual tumors, different clinical responses and different levels of prognostic value of the immune infiltrate have been reported $(10,14,19,20)$. Prognostic role of the presence of tumor lymphocytes (TILs) in melanoma has long been known, and today melanoma is one of the most successfully treated tumors with immunotherapy (21) A number of studies evaluating TILs in melanoma in different ways, using different evaluation methods and techniques (HE, IHC), in primary site and metastatic lesions, and most studies have shown an association between the presence of lymphocytic infiltrate and good prognosis and good response to therapy (22 129). Similarly, the prognostic potential of TILs in colorectal cancer has also long been known. Particularly interesting is the ability to predict tumor MSI (microsatellite instability) by simply evaluating HE TILs in the tumor, with greater or less precision, which is a marker of dMMR (MissMatchRepair deficiency), one of the two major pathogenetic pathways of colorectal cancer, and that is of prognostic and predictive value (23). In addition, TILs have been shown to be an independent prognostic factor in all types of colorectal cancer, independent of MSI status, as well as predictor of response to neoadjuvant therapy in rectal cancer (24). Concerning other tumors of the digestive system, studies have been conducted on the role of TILs in gastric, pancreatic and hepatocellular carcinoma (22), but at the present time without concrete positive results and 
with the need for larger prospective studies. In the group of gynecologic tumors, interest in TILs in endometrial cancer is mainly associated with the possibility of predicting MSI /dMMR status, similar to colorectal cancer (22), and encouraging results have been observed in studies of the role of TILs in ovarian cancer, although obvious differences in the prognostic role of TILs have been observed, depending on the type of cellular infiltrate as well as in which compartment they were evaluated (25). In the group of urogenital tumors, the results differ from seemingly immunogenic bladder cancer, which showed not only prognostic but also predictive role of TILs (22), via renal cancer, in which some studies clearly highlighted negative association of TILs and prognosis (22), which has been shown to exist due to immunosuppressive cells in the infiltrate (such as $\mathrm{T}$ regulatory cells), to clearly non-immunogenic prostate cancer, whose response to immunotherapy remains to be investigated (22). Non-small cell lung cancer is considered to be a highly immunogenic tumor, given the multitude of mutations detected and the resulting genomic instability and neo-antigen formation, which is why the mechanisms of immune response have been of great clinical interest and have been well investigated. TILs have been shown to be associated with good prognosis, and lung cancer is also one of the tumors with excellent results in immunotherapy treatment $(26,27)$. The role of TILs has been investigated in a heterogeneous group of head and neck tumors as well as in brain tumors (22), and it seems that in the future a more accurate, simple and standardized methodology, first developed with breast cancer and subsequently reproduced in the other mentioned tumor sites, will be used to evaluate the clinical value of TILs also in other solid tumors.

\section{Tumor - infiltrating lymphocytes in breast cancer}

Numerous studies have evaluated the value of lymphocytic infiltrate in breast cancer (BC) and, based on this knowledge, the first consensus on the standardization of TILs evaluation in solid tumors has been established on the BC model (28). Various evaluation methods have been used in TILs studies in BC, from HE, IHC to molecular methods of gene expression (29-31). Most relevant studies are retrospective TILs analyzes on samples from large prospective cohort studies conducted in either a population of patients with early or locally advanced, luminal, HER2-positive or triple negative breast cancer (TNBC), who have investigated the effect of some chemotherapy approach, in adjuvant or neoadjuvant setting, on tumor tissue specimens obtained by core biopsy or complete specimens obtained operatively, as well as in paired specimens of primary tumor and metastatic site, in case of advanced disease (29,32-37). Studies have shown very diverse results, and these differences are mainly explained by differences in the methodology and technology applied, the method of evaluation and the selection of infiltrate sections for evaluation, and the different sample sizes on which the evaluation was conducted, which affects the statistical significance of the results obtained. Nevertheless, the retrospective nature of most of the studies, which provided the first and crucial information thus far, proved to be non-inferior in this case and the results obtained may be considered relevant (38). Most BCs show some degree of lymphocytic infiltrate. The presence of a higher proportion of TILs was observed in more aggressive cancers, with negative endocrine receptors, high grade, basaloid characteristics, and BRCA mutants. Lymphocyte-predominant type of BC (LPBC) is defined as one in which $50-60 \%$ of tumor is infiltrated by lymphocytes. It is more common among tumors of TNBC (20\%) or HER2-positive immunophenotype (16\%), compared to luminal, ER-positive $(6 \%)$ (39) The stromal TILs were mainly evaluated by the HE method, which proved to be of the greatest importance, while the intratumoral TILs played a minor role $(22,28)$, which may also be due to limitations of the HE method itself, which is why the role and significance of the intratumoral TILs are further evaluated by IHC. It has been found that evaluation of TILs on core biopsy specimens closely correlates with post-operative specimen analysis and that both specimens can be used equally (22). Studies using the HE method of evaluating TILs in the results correlated highly with studies using the IHC method as well as mRNA profiling $(22,28-$ 31). The presence of lymphocytic infiltrate was also observed in DCIS specimens, most commonly those with HER2 positive, and the percentage appears to be approximately between that in normal breast tissue (where it is low) and that in invasive carcinoma (where it is high) (40). Compared to the 
primary site, lymphocytic infiltrate was less prevalent in metastatic lesions, which is consistent with the theory of immunoediting and tumor escape from immune control $(22,37)$. In prognostic terms, TILs are associated with better disease-free survival (DFS) and overall survival (OS) most reliably in TNBC and HER2-positive BC, and no statistically significant benefit was observed in luminal tumors (especially in luminal A variant) $(41,42)$. Furthermore, when they were prognostically favorable indicator, TILs showed that for every $10 \%$ of infiltrate intensification, the risk of disease recurrence and death decreased by about 10$20 \%$ (34), indicating the need for TILs expression as continuous variables $(22,28,35)$. Given that both chemotherapy and endocrine therapy exert their effects to some extent by immunomodulatory mechanisms, it is not surprising that results suggesting predictive role for TILs present in the pretherapeutic bioptic sample for response to neoadjuvant anthracycline therapy, where they have been found to be independent predictors of pCR (35), or an adjuvant combination of anthracyclines and taxanes (32), as well as aromatase inhibitor therapy (43), and have been shown to be a good predictor of response to trastuzumab therapy (33). Thus, the described results undoubtedly demonstrate the predictive and prognostic role of TILs in TNBC and HER2-positive BC, and the clinical value of evaluating TILs in BC is related to the development of predictive risk models, (given the continuity of the variable), therapeutic decision making for use of adjuvant and neoadjuvant chemotherapy, first and further lines of treatment, and with the highly interesting benefit of immunotherapy today.

\section{Tumor - infiltrating lymphocytes in triple-negative breast cancer}

TNBC is the most aggressive BC subtype in addition to HER2, a tumor loaded with many mutations and thus genomic instability, the result of which is a multitude of tumor neo-antigens, making TNBC the most immunogenic BC. This explains the highest prevalence of lymphocytic infiltrate in TNBC, as well as the highest incidence of $\mathrm{LPBC}$ among this type of $\mathrm{BC}(44,30)$. Research into the role of TILs in BC has so far yielded the most significant results in the TNBC population. A series of studies and meta-analyzes have demonstrated the possible association of TILs with prog- nosis in TNBC $(29,33,34,41,42,45)$. Results relate to the impact of TILs on improved disease-free survival (DFS), overall survival (OS), survival without distant dissemination (DDFS), reduction of disease recurrence locally and remotely (45). This favorable prognostic impact of TILs has been shown to be independent of age, lymph node status, tumor size and histologic grade, peritumor vascular invasion, or Ki67 proliferation index (40). Further subdivision of TNBC into core - basal type (CBP) and 5NP revealed no significant difference in the clinical value of TILs expression. Some studies have shown that there is no statistically significant effect on OS in 5NPs, however relevant data for the $5 \mathrm{NP}$ population is scarce $(46,45)$. Despite the different and in some studies conflicting results of the prognostic value of IHC analyzed separately for different subpopulations of TILs (CD8 + , FOXP3 +), pooled analyzes show that there is really no enough strong data to support the existence of this difference in clinical value (45). Likewise, according to some studies, the prognostic value of TILs in TNBC seem to be more significant if analyzed without the influence of chemotherapy: HR (hazard ratio) for OS in TIL-rich tumors in the presence of chemotherapy was found to be lower in compared to that without chemotherapy (46), but several studies and pooled multivariate analyzes have shown that TILs are a good independent predictive indicator of response to chemotherapy $(31,35,47,48,49)$. As mentioned above, the presence of TILs in a pre-therapeutic biopsy specimen may predict good response to therapy and the achievement of pCR $(50,51)$, and the presence of TILs in the residual tumor tissue, following treatment, is also a prognostic indicator of better metastasis-free survival and overall survival $(52,53)$. Finally, enhanced expression of PD1 and PDL1 was demonstrated on activated immune cells, much more than on tumor cells, in TIL-rich TNBC $(54,55)$. This signaling pathway is known to be the target of today's immunotherapy approaches with checkpoint inhibitors, such as already mentioned pembrolizumab and atezolizumab, although with different ways of evaluation of PDL1 positivity (from PDL1 positive immune cells exclusively, for atezolizumab, to combined positive score, of immune and tumor cells, carrying PDL1, among all cells, for pembrolizumab). Role of PDL1 positivity was crucial in these trials, and only the PDL1 positive tumors responded, yet significantly 
more and better in those trials where immunotherapy was combined with chemotherapy $(12,13,56)$. Therefore, TILs in TNBC, as an indirect indicator of PDL1 expression, is seriously considered for use as a marker in routine clinical practice for its ease and cost-effectiveness of detection.

\section{CONCLUSION}

Therapeutic potential of the immune systemtumor interaction is truly great. The use of this potential has shifted from initial unselective attempts to exploit the immune system, to more natural interventions and release of an intrinsic immune response, such as blocking immune inhibitory checkpoints. The success of such an approach appears to be more likely in the presence of indicators of intrinsic immune response activity, which is an immune infiltrate in the tumor. Understanding the origin, composition and function of the immune infiltrate in a tumor is the basis for more accurate assessment and prediction of the success of immunotherapy in the fight against cancer.

\section{REFERENCES}

1. Abbas A, Lichtman A, Pillai S. Cellular and Molecular Immunology. 9th ed. Elsevier; 2017.

2. Vigneron N. Human Tumor Antigens and Cancer Immunotherapy. Biomed Res Int. 2015;2015:1-17.

3. Finn OJ. A Believer's Overview of Cancer Immunosurveillance and Immunotherapy. J Immunol. 2018 Jan 15;200(2):385-91.

4. Swann JB, Smyth MJ. Immune surveillance of tumors. J Clin Invest. 2007 May 1;117(5):1137-46.

5. Whiteside TL. Immune responses to malignancies. J Allergy Clin Immunol. 2010 Feb;125(2):S272-83.

6. Grivennikov SI, Greten FR, Karin M. Immunity, Inflammation, and Cancer. Cell. 2010 Mar;140(6):883-99.

7. Dunn GP, Old LJ, Schreiber RD. The Three Es of Cancer Immunoediting. Annu Rev Immunol. 2004 Apr;22 (1):329-60.

8. Buchbinder EI, Desai A. CTLA-4 and PD-1 Pathways. Am J Clin Oncol. 2016 Feb;39(1):98-106.

9. Nathan MR, Schmid P. The emerging world of breast cancer immunotherapy. The Breast. 2018 Feb;37: 200-6.

10. Nakasone ES, Hurvitz SA, McCann KE. Harnessing the immune system in the battle against breast cancer. Drugs Context. 2018 Feb 12;7:1-21.

11. Sharma P, Allison JP. Immune Checkpoint Targeting in Cancer Therapy: Toward Combination Strategies with Curative Potential. Cell. 2015 Apr;161(2):205-14.
12. Nanda R, Liu MC, Yau C, Asare S, Hylton N, Veer LV, et al. Pembrolizumab plus standard neoadjuvant therapy for high-risk breast cancer (BC): Results from ISPY 2. J Clin Oncol. 2017 May 20;35(15_suppl):506-506.

13. Schmid P, Adams S, Rugo HS, Schneeweiss A, Barrios $\mathrm{CH}$, Iwata $\mathrm{H}$, et al. Atezolizumab and Nab-Paclitaxel in Advanced Triple-Negative Breast Cancer. N Engl J Med. 2018 Nov 29;379(22):2108-21.

14. Hanahan D, Weinberg RA. Hallmarks of Cancer: The Next Generation. Cell. 2011 Mar;144(5):646-74.

15. Mahmoud SMA, Paish EC, Powe DG, Macmillan RD, Grainge MJ, Lee AHS, et al. Tumor-Infiltrating CD8 + Lymphocytes Predict Clinical Outcome in Breast Cancer. J Clin Oncol. 2011 May 20;29(15):1949-55.

16. Oldford SA, Robb JD, Codner D, Gadag V, Watson $\mathrm{PH}$, Drover S. Tumor cell expression of HLA-DM associates with a Th1 profile and predicts improved survival in breast carcinoma patients. Int Immunol. 2006 Sep 5;18(11):1591-602.

17. Zhang Q, Qin J, Zhong L, Gong L, Zhang B, Zhang Y, et al. CCL5-Mediated Th2 Immune Polarization Promotes Metastasis in Luminal Breast Cancer. Cancer Res. 2015 Oct 15;75(20):4312-21.

18. Brunner-Weinzierl MC, Rudd CE. CTLA-4 and PD-1 Control of T-Cell Motility and Migration: Implications for Tumor Immunotherapy. Front Immunol. 2018 Nov $27 ; 9$.

19. Santegoets SJ, van Ham VJ, Ehsan I, Charoentong P, Duurland CL, van Unen V, et al. The Anatomical Location Shapes the Immune Infiltrate in Tumors of Same Etiology and Affects Survival. Clin Cancer Res. 2019 Jan 1;25(1):240-52.

20. Stoll G, Zitvogel L, Kroemer G. Immune infiltrate in cancer. Aging (Albany NY). 2015 Jun 25;7(6):358-9.

21. Dummer R, Hauschild A, Lindenblatt N, Pentheroudakis G, Keilholz U. Cutaneous melanoma: ESMO Clinical Practice Guidelines for diagnosis, treatment and follow-up. Ann Oncol. 2015 Sep 26;26(suppl 5): v126-32.

22. Hendry S, Salgado R, Gevaert T, Russell PA, John T, Thapa B, et al. Assessing Tumor-Infiltrating Lymphocytes in Solid Tumors. Adv Anat Pathol. 2017 Nov;24 (6):311-35.

23. Smyrk TC, Watson P, Kaul K, Lynch HT. Tumor-infiltrating lymphocytes are a marker for microsatellite instability in colorectal carcinoma. Cancer. 2001 Jun 15;91(12):2417-22.

24. Rozek LS, Schmit SL, Greenson JK, Tomsho LP, Rennert HS, Rennert G, et al. Tumor-Infiltrating Lymphocytes, Crohn's-Like Lymphoid Reaction, and Survival From Colorectal Cancer. JNCI J Natl Cancer Inst. 2016 Aug;108(8).

25. Hwang W-T, Adams SF, Tahirovic E, Hagemann IS, Coukos G. Prognostic significance of tumor-infiltrating T cells in ovarian cancer: A meta-analysis. Gynecol Oncol. 2012 Feb;124(2):192-8. 
26. Donnem T, Kilvaer TK, Andersen S, Richardsen E, Paulsen EE, Hald SM, et al. Strategies for clinical implementation of TNM-Immunoscore in resected nonsmall-cell lung cancer. Ann Oncol. 2016 Feb;27(2): 225-32.

27. Planchard D, Popat S, Kerr K, Novello S, Smit EF, Faivre-Finn $\mathrm{C}$, et al. Metastatic non-small cell lung cancer: ESMO Clinical Practice Guidelines for diagnosis, treatment and follow-upt. Ann Oncol. 2018 Oct 1;29(Supplement_4):iv192-237.

28. Salgado R, Denkert C, Demaria S, Sirtaine N, Klauschen F, Pruneri G, et al. The evaluation of tumorinfiltrating lymphocytes (TILs) in breast cancer: recommendations by an International TILs Working Group 2014. Ann Oncol. 2015 Feb;26(2):259-71.

29. Adams S, Gray RJ, Demaria S, Goldstein L, Perez EA, Shulman LN, et al. Prognostic Value of Tumor-Infiltrating Lymphocytes in Triple-Negative Breast Cancers From Two Phase III Randomized Adjuvant Breast Cancer Trials: ECOG 2197 and ECOG 1199. J Clin Oncol. 2014 Sep 20;32(27):2959-66.

30. Ali HR, Provenzano E, Dawson S-J, Blows FM, Liu B, Shah $\mathrm{M}$, et al. Association between CD8+ T-cell infiltration and breast cancer survival in 12439 patients. Ann Oncol. 2014 Aug;25(8):1536-43.

31. West NR, Milne K, Truong PT, Macpherson N, Nelson $\mathrm{BH}$, Watson $\mathrm{PH}$. Tumor-infiltrating lymphocytes predict response to anthracycline-based chemotherapy in estrogen receptor-negative breast cancer. Breast Cancer Res. 2011 Dec 8;13(6):R126.

32. Loi S, Sirtaine N, Piette F, Salgado R, Viale G, Van Eenoo F, et al. Prognostic and Predictive Value of TumorInfiltrating Lymphocytes in a Phase III Randomized Adjuvant Breast Cancer Trial in Node-Positive Breast Cancer Comparing the Addition of Docetaxel to Doxorubicin With Doxorubicin-Based Chemotherapy: BIG 02-98. J Clin Oncol. 2013 Mar;31(7):860-7.

33. Loi S, Michiels S, Salgado R, Sirtaine N, Jose V, Fumagalli $\mathrm{D}$, et al. Tumor infiltrating lymphocytes are prognostic in triple negative breast cancer and predictive for trastuzumab benefit in early breast cancer: results from the FinHER trial. Ann Oncol. 2014 Aug;25(8): 1544-50.

34. Loi S, Drubay D, Adams S, Pruneri G, Francis PA, Lacroix-Triki M, et al. Tumor-Infiltrating Lymphocytes and Prognosis: A Pooled Individual Patient Analysis of Early-Stage Triple-Negative Breast Cancers. J Clin Oncol. 2019 Mar;37(7):559-69.

35. Denkert C, Loibl S, Noske A, Roller M, Müller BM, Komor M, et al. Tumor-Associated Lymphocytes As an Independent Predictor of Response to Neoadjuvant Chemotherapy in Breast Cancer. J Clin Oncol. 2010 Jan;28(1):105-13.

36. Buisseret L, Desmedt C, Garaud S, Fornili M, Wang X, Van den Eyden G, et al. Reliability of tumor-infiltrating lymphocyte and tertiary lymphoid structure assessment in human breast cancer. Mod Pathol. 2017 Sep 16;30(9):1204-12.
37. Ogiya R, Niikura N, Kumaki N, Bianchini G, Kitano S, Iwamoto $\mathrm{T}$, et al. Comparison of tumor-infiltrating lymphocytes between primary and metastatic tumors in breast cancer patients. Cancer Sci. 2016 Dec;107 (12):1730-5.

38. Pruneri G, Vingiani A, Denkert C. Tumor infiltrating lymphocytes in early breast cancer. The Breast. 2018 Feb;37:207-14.

39. Stanton SE, Disis ML. Clinical significance of tumorinfiltrating lymphocytes in breast cancer. J Immunother Cancer. 2016 Dec 18;4(1):59.

40. Pruneri G, Vingiani A, Bagnardi V, Rotmensz N, DeRose A, Palazzo A, et al. Clinical validity of tumorinfiltrating lymphocytes analysis in patients with triple-negative breast cancer. Ann Oncol. 2016; 27: 249-256.

41. Mao Y, Qu Q, Chen X, Huang O, Wu J, Shen K. The Prognostic Value of Tumor-Infiltrating Lymphocytes in Breast Cancer: A Systematic Review and MetaAnalysis. Tagliabue E, editor. PLoS One. 2016 Apr 13; 11(4):e0152500.

42. Yu X, Zhang Z, Wang Z, Wu P, Qiu F, Huang J. Prognostic and predictive value of tumor-infiltrating lymphocytes in breast cancer: a systematic review and meta-analysis. Clin Transl Oncol. 2016 May 12;18(5): 497-506.

43. Chan MS, Wang L, Felizola SJ, Ueno T, Toi M, Loo W, et al. Changes of tumor infiltrating lymphocyte subtypes before and after neoadjuvant endocrine therapy in estrogen receptor-positive breast cancer patients an immunohistochemical study of cd8+ and foxp3+ using double immunostaining with correlation to the pat. Int J Biol Markers. 2012;27(4):295-304.

44. Liu Z, Li M, Jiang Z, Wang X. A Comprehensive Immunologic Portrait of Triple-Negative Breast Cancer. Trans Oncol. 2018 April;11(2):311-329.

45. Ibrahim EM, Al-Foheidi ME, Al-Mansour MM, Kazkaz GA. The prognostic value of tumor-infiltrating lymphocytes in triple-negative breast cancer: a metaanalysis. Breast Cancer Res Treat. 2014;148:467-476.

46. Liu S, Lachapelle J, Leung S, Gao D, Foulkes WD, Nielsen TO. CD8+ lymphocyte infiltration is an independent favorable prognostic indicator in basal-like breast cancer. Breast Cancer Res. 2012;14:R48.

47. Tan LT, Liu J, Cheng K, Wang XH, Zhang YZ, Teng XF, et al. Prediction Role of Tumor-Infiltrating Lymphocytes in Triple Negative Breast Cancer Patients Received the Neoadjuvant Chemotherapy: A MetaAnalysis. Chemo Open Access. 2017; 6:4

48. Asano Y, Kashiwagi S, Goto W, Takada K, Takahashi K, Hatano T, et al. Prediction of Treatment Response to Neoadjuvant Chemotherapy in Breast Cancer by Subtype Using Tumor-infiltrating Lymphocytes. Anticancer Res. 2018;38:2311-2321.

49. Herrero -Vicent C, Guerrero A, Gavilá J, Gozalbo F, Hernández A, Sandiego S, et al. Predictive and prog- 
nostic impact of tumour-infiltrating lymphocytes in triple-negative breast cancer treated with neoadjuvant chemotherapy. Ecancer. 2017; 11:759.

50. Mao Y, Qu Q, Zhang Y, Liu J, Chen X, Shen K. The Value of Tumor Infiltrating Lymphocytes (TILs) for Predicting Response to Neoadjuvant Chemotherapy in Breast Cancer: A Systematic Review and MetaAnalysis. PLoS ONE. 2014 Dec 12; 9(12): e115103.

51. Ono M, Tsuda H, Shimizu C, Yamamoto S, Shibata T, Yamamoto $\mathrm{H}$, et al. Tumor-infiltrating lymphocytes are correlated with response to neoadjuvant chemotherapy in triple-negative breast cancer. Breast Cancer Res Treat. 2012;132:793-805.

52. Dieci MV, Criscitiello C, Goubar A, Viale G, Conte P, Guarneri V, et al. Prognostic value of tumor-infiltrating lymphocytes on residual disease after primary chemotherapy for triple-negative breast cancer: a retrospective multicenter study. Ann Oncol. 2014;25: 611-618.

53. Garcia-Martinez E, Gil GL, Benito AC, Gonzalez-Billalabeitia E, Conesa MAV, Garcia TG, et al. Tumor infil- trating immune cell profiles and their change after neoadjuvant chemotherapy predict response and prognosis of breast cancer. Breast Cancer Res. 2014; 16:488.

54. Sabatier R, Finetti P, Mamessier E, Adelaide J, Chaffanet M, Ali HR, et al. Prognostic and predictive value of PDL1 expression in breast cancer. Oncotarget. 2014 Dec 31; 6:7.

55. Kitano A, Ono M, Yoshida M, Noguchi E, Shimomura A, Shimoi T, et al. Tumour-infiltrating lymphocytes are correlated with higher expression levels of PD-1 and PD-L1 in early breast cancer. ESMO Open. 2017 Jan 17;2:e000150.

56. Cortes J, Cescon DW, Rugo HS, Nowecki Z, Im SA, Yusof MM, et al. Pembrolizumab plus chemotherapy versus placebo plus chemotherapy for previously untreated locally recurrent inoperable or metastatic triple-negative breast cancer (KEYNOTE-355): a randomised, placebo-controlled, double-blind, phase 3 clinical trial. The Lancet. 2020; 396: 1817-1828.

Sažetak

\title{
IMUNITET I RAK: ULOGA TUMOR-INFILTRIRAJUĆIH LIMFOCITA KOD TROSTRUKO NEGATIVNOG KARCINOMA DOJKE
}

\author{
A. Tečić Vuger, R. Šeparović, Lj. Vazdar, M. Pavlović, P. Linarić, S. Šitić, M. Šepetavc i D. Vrbanec
}

Tumor stimulira specifične urođene i stečene imunološke mehanizme. Glavni nositelji imunološkog odgovora tijela na tumor su T limfociti, a glavni mehanizam je ubijanje tumorskih stanica citotoksičnim T limfocitima CD8 +. U nekim slučajevima imunološki sustav također može imati protumorsku ulogu, što je paradoks, s obzirom na to da je poznato da upalno stanje potiče rast tumora. Jedna od glavnih karakteristika tumora je izbjegavanje imunološkog odgovora, posebno mehanizmima inhibicije aktivnog antitumorskog imunološkog odgovora putem dva glavna fiziološka inhibitorna signala, CTLA-4 i PD1 / PDL1. Blokada ovih kontrolnih točaka, koji su mehanizmi inhibicije T stanica, nedavno je dala najbolje rezultate u imunoterapijskom pristupu liječenju karcinoma. Imuni infiltrat u tumoru, kao dokaz postojanja aktivnog unutarnjeg odgovora organizma, je heterogen, a sastav se često razlikuje između različitih tumora i tumorskih stanica i uglavnom se dijeli na dvije glavne stanične linije: limfoidnu i mijeloidnu. O vrsti staničnih linija u imunološkom infiltratu i njihovoj aktivaciji i orijentaciji ovisi klinički odgovor kod različitih tumora. Dobro je poznato da imuni infiltrat, posebno limfociti koji infiltriraju tumor (TIL), mogu predvidjeti odgovor na terapiju i imati prognostičku ulogu. Kod nekih solidnih tumora oni su dobar znak, dok kod nekih signaliziraju lošiju prognozu. Brojne studije procjenjivale su ulogu limfocitnog infiltrata u raku dojke (BC), a na temelju tog znanja uspostavljen je prvi koncenzus o standardizaciji procjene TIL u solidnim tumorima na BC modelu. Prognostičkoj ulozi TIL u trostruko negativnom raku dojke posvećeno je najviše pažnje.

KLJUČNE RIJEČI: antitumorski imunološki odgovor, tumor infiltrirajući limfociti, imunoterapija, trostruko negativni rak dojke 